\title{
Brand Personality's Effect on Brand Loyalty: In Case of National Banks from Srikakulam City, Andhra Pradesh, India
}

\author{
Koppalavenugopal, D. Vishnu murty
}

\begin{abstract}
The association between Brand personality and Brand Loyalty is considered to the study of imperative with respect to the influencing factors such as Sincerity, Competence, Excitement, Sophistication and Ruggedness on consumers' heart share. Though the previous studies exist on this concept, the geographical area of Srikakulam city and emphasizing on banking sector specifically focusing on nationalized banks have made the study unusual. With an objective of assessing the influence of brand personality on brand loyalty, the study has been carried out by backed up with methodology blend of mixed approach, survey design, cross sectional research, convenience sampling technique, data collection through structured questionnaire and data analysis with descriptive and inferential statistics. The interesting results out of the analysis have been associated with independent and dependant variables relationship and impact are explored well with the conclusions drawn followed by the objective centered recommendations to the industry.
\end{abstract}

Keywords: Brand Personality, Brand Loyalty, Bank branding, Rural Banking

\section{INTRODUCTION}

Latest developments of technology and social networks brings the information effectively accessible to the target market, the concept of branding is operated in association with the progression of certain emerging countries with globalized economy(Aaker, 1996, 2010; Keller, 2003; Keller and Lehmann, 2006), further puts managers efforts challenging enough.

Branding was initiated around 1500 BC by Greeks marking their cattle for identification; the trends now show that the concept of attention is the first focus and later marketers develop and focus on the other advantages.

Fournier (1998) reveals that the relationship with the customers for longevity with functional and emotional associations would result into the partnership with respect to the brand development in the way of the product being promoted by both marketer and consumer.

Kapferer (2008) also concedes the relationship building and maintenance involve profound emotional links which lead to customer loyalty which is a central point of attention for business giants. A good number of researches also add that the loyal consumers advocate brand through WOM communications with an optimistic view without expecting any monetary benefit which can obviously be considered as the valuable group (Ganesh et al., 2000, p. 65; Zeithaml et

Revised Manuscript Received on 14 August, 2019.

Dr. Koppalavenugopal, Professor, Department of Management Studies, AITAM, Tekkali, Srikakulam, AP, India(Email koppala71@gmail.com)

Dr. D. Vishnu murty, Dean and Professor in Management Studies, AITAM, Tekkali, Srikakulam, AP, India(Email: vishnudevi33@gmail.com) al., 1996). Moreover, loyalty pays more price for they never be price sensitive (Krishnamurthi\& Raj, 1991) where by the afford of marketing is reduced and the cost as one of the burden would be relaxed.

Loyal customers with respect to the buyers for long period of time must have been retained with the company and its brands are found to be lucrative for the company since attracting new customers is more expensive than loyal customers for advertising promotion, sales, and start-up operating expenses (Reichheld, 1996).

Martineau (1958) with his theoretical foundation of brand personality (BP) as early as in the 1950 s stated that consumers exceptionally focus on the personality when there are homogeneous attributes such as same prices, quality of products, and equally good services and the brand image is much useful to craft the desired personality.

Brand personality as a strategic instrument that shapes the brand's communication which reflects and communicates itself through its personalities in the minds of consumers, which further establishes hardcore loyal relationships with the consumers. Hence, it is extremely imperative to assess the relationship between the input elements of brand personality with loyalty outcomes. Though a few researchers like Plummer (1985) and David Aaker (1996) have emphasized the positive relationship between brand personality and brand loyalty (BL), this study made a unique attempt by connecting the concept to service sector and national banks in specific.

The customers who use the services of banks with a significant increased size in the study area, Srikakulam city, need to be strategically designed with outstanding features. Consumers' take an account and utilize the services well, if the brand is appropriate with their personality. If the brand is related to the consumer's unique characteristics, the consumer will purchase and use that service frequently. Then becomes loyal customers that are highly helpful to the banks in the way of talking about the brands' positive performances and its services to new customers by word of mouth communications. These types of customers were found in the researcher's study area, so the researchers conducted with these consumers at work time to investigate the effect of brand personality on brand loyalty. Brand with distinct nature results exceptional brand personality, which leads customers to perceive and develop a strong connection to the brand meant for long lasting and unswerving (Doyle, 1990). Therefore, this study conducted with the focus of 


\section{BRAND PERSONALITY'S EFFECT ON BRAND LOYALTY: IN CASE OF NATIONAL BANKS FROM SRIKAKULAM CITY, ANDHRA PRADESH, INDIA}

describing the various factors responsible for determining the effect of BP on BL. Since the consumers in semi urban place like in Srikakulam city are well and much habituated with the practices of nationalized banks, the research aimed at the loyal customers of national banks only.

\section{STATEMENT OF THE PROBLEM}

As noted by Kothari (2004) recognition of a research problem is the primary requirement to conducting investigation. The purpose of the research problem is said to be the one which requires an investigator to locate the best accessible result to the given problem. That is, the investigator wants to find out the greatest course of accomplishment through which research objective will be achieved optimally in the situation of a given solution

The research problem is aimed to investigate the effect of BP on BL from a consumer's perspective of national banks from Srikakulam city. The transition value of consumers brand personality to brand loyalty has not been widely recognized and developed in service sector and banking services in specific. Aaker (1997) presented the empirical results of her research on the measurement of brand personality but the issues of why and how BP affects consumers' BL, have not been addressed. Many other researchers also tried to look the effect of $\mathrm{BP}$ on $\mathrm{BL}$ in different perspectives like identification and recognition (Kim, Han, \& Park, 2001) in which positive relationships between attractiveness, distinctiveness, and self-expressive value of brand personality are statistically significant on consumers' brand identification that reflects directly on word-of mouth reports and indirectly on brand loyalty.

Many researchers argue that when consumers purchase products, they are related to the individual's unique characteristics. So, individual's unique characteristics will be affect brand loyalty. According to Lin (2010) in his study, the relationship of consumer personality trait, brand personality and brand loyalty were explored.

In this study, the researchers believed that the elements pertaining to BP would be vital enough in the assessment of how consumers develop their brand loyalty when they pursue certain services from branded banks.

Additionally, these studies carried out in different countries in different concepts and products and in our country it is new concept and there is no enough research through this problem. Therefore, the gap would be filled by the initiation to carry out the study. Furthermore, the factors underlying the effect of brand personality on brand loyalty of consumers based on BP dimensions which are Sincerity, Competence, Excitement, Sophistication and Ruggedness context remains immature and rudimentary, more in the study area context. Consequently, this study has carried out to fill these gaps and to get insight to understand the effect of brand personality on brand loyalty of consumers of nationalize banks in Srikakulam city such as State Bank Of India (SBI), State Bank of Hyderabad (SBH), Bank of India, Allahabad Bank, Bank of Baroda and UCO Bank.

\section{OBJECTIVE OF THE STUDY}

The objectives of the research is

To assess the effect of brand personality on brand Loyalty: incase of national bank consumers in Srikakulam city

To evaluate the effect of Brand Sincerity, Brand Competence, Brand Excitement, Brand Sophistication and Brand Ruggedness on Brand Loyalty of consumers of nationalized banks in Srikakulam city.

\section{LITERATURE REVIEW}

\subsection{Dimensions of brand personality}

Purchasing one particular brand over another by certain consumers must highly be influenced by media mix, especially social media now a days, wherein the brand personalities are stable enough with both own self-concept and sometimes desired self-concept which dominate actual image of the product and services. Certain human characteristics set together to match up with product related attributes tend to oblige utilitarian function in the form of symbolic or self-expressive function (Keller 1993).

Aaker J (1997) made an attempt of brand personality categorized by five factors i.e. Brand Sincerity, Brand Excitement, Brand Competency, Brand Ruggedness and Brand Sophistication. Several brands choose characters as a liaison to articulate their brand personality and smoothen their brand storytelling process. Customers brand loyalty as dependent variable in a linear regression model was used to study the significance of each of five brand personality variables.

- Brand sincerity as the first element of brand personality has certain traits such as quality, comfort, durability, reality, benefit, originality, friendliness, and honesty. Sincerity of the brand may be understood by the consumer through any of the elements strongly influence the brand which in turn would help in line with appeal to customers.

- $\quad$ Brand excitement contains style, occasion, feeling, feeling different, update, self-governing, and unique which are attracted by the customers at the standpoint of lifestyles of adventure and excitement.

- The attributes epitomized by brand competence are fashionable, corporate, leader, confident, reliability, affinity, and faithfulness which may be presented as an alternative value.

- Brand sophistication comprises rough and touch, frequent washing, modern, masculine, and outside appearance pertains most of the times to upper-class and above with the products feeling rich..

- Brand ruggedness encloses user feeling, upperclass, glamorous, smooth, charming, user personality and consumer preference for they gravitate toward the practical and demand more than competence.

\subsection{Brand loyalty}

Loyalty as a core dimension of brand equity well defined by many researchers from which Aaker (1991) symbolizes as a constructive mind set toward brand which leads to 
invariable purchasing of the brand over time and can assess a brand in value terms where loyalty out of the brand can generate significant revenue. Brand loyalty is measured by 8 components, which have been developed by Ratchford (1987) are (1) Continued to choose this brand again; (2) This brand is the best choice; (3) Loyal patron of this brand; (4) Recommend this brand to others; (5) Intention to purchase this brand again; (6) This brand is the first \& prefer choice; (7) Speak positively about this brand; (8) Encourage others to buy this brand.

\section{RESEARCH METHODOLOGY}

The researcher has used a quantitative research approach in this research to describe the influences of brand personality (independent variables) on brand loyalty (dependent variables)and to check the hypotheses of the research as well. The researchers have employed descriptive research design in this study and have described various variables that influence brand loyalty such as sincerity, excitement, competence, sophistication, and ruggedness. Survey study was employed with structured questionnaires for respondents which are related to the study in order to solve the problem and the cross sectional research design has been carries out as well. The unit of analysis of the study comprises individual customers who are occasional and regular users of banking brands above 25 years old.

This study employed non-probability sampling because the sampling frame is unavailable and infinite population (Saunders, Lewis, \&Thornhill, 2009) by using the formula developed by (Cochran, 1963, p. 75) \& (Israel, 1992) as follows:

$$
\rightarrow \mathrm{n}=\frac{z^{2} p . q}{e^{2}} \rightarrow \mathrm{n}=\frac{(1.96)^{2}(0.5)(0.5)}{(0.05)^{2}}=385
$$

The researchers used non probability sampling technique (convenience sampling) due to large number of sample unit, time and cost constraint. To gather the primary data, researchers used a structured questionnaire which contains close ended items with five point Likert scale basis to obtain first hand information through direct solicitation of responses from the respondents (Yin, 2003). The secondary data was collected from existing literature reviews written in relation to this study. The data screened and coded into SPSS (20.0) software. The data-processing has been carried by ensuring the accuracy, validity and reliability of the research.

\section{ANALYSIS\& RESULTS}

As discussed above, the study has taken place in Srikakulam city with an aim to collect the data from the determined size 385 but due to severe non sampling errors of non-response and data insufficiency and gathering problems, thus the qualified size has been confined to 259 only. The analysis is made for the same as follows

\subsection{Demographic analysis:}

\section{Table 1: Sex}

\begin{tabular}{|c|l|l|l|l|}
\hline & Frequency & Percent & Valid Percent & Cumulative Percent \\
\hline Validfemale & 44 & 17.0 & 17.0 & 17.0 \\
male & 215 & 83.0 & 83.0 & 100.0 \\
Total & 259 & 100.0 & 100.0 & \\
\hline
\end{tabular}

Source: statistical output of the survey
It can be understood through table 1 that the percentage of male respondents $(83 \%)$ are much more than female $(17 \%)$. Srikakulam is considered as the backward district and the involvement of female in extensive banking transactions are found poor and the loyalty is a far way away for many of them.

\begin{tabular}{|c|c|c|c|c|c|}
\hline & Frequency & Percent & $\begin{array}{l}\text { Valid } \\
\text { Percent }\end{array}$ & $\begin{array}{c}\text { Cumulative } \\
\text { Percent }\end{array}$ \\
\hline \multirow{6}{*}{ Valid } & $<25$ & 25 & 9.7 & 10.0 & 10.0 \\
\hline & $\begin{array}{c}26- \\
35\end{array}$ & 138 & 53.3 & 55.2 & 65.2 \\
\hline & $\begin{array}{c}36- \\
45\end{array}$ & 77 & 29.7 & 30.8 & 96.0 \\
\hline & $\begin{array}{l}46- \\
55\end{array}$ & 8 & 3.1 & 3.2 & 99.2 \\
\hline & $>56$ & 2 & .8 & .8 & 100.0 \\
\hline & Total & 250 & 96.5 & 100.0 & \\
\hline \multicolumn{2}{|c|}{ Missing } & 9 & 3.5 & & \\
\hline \multicolumn{2}{|c|}{ Total } & 259 & 100.0 & & \\
\hline
\end{tabular}

Source: statistical output of the survey

According to Table 2, the age of respondents that have been loyal to the banks majorly in between 26 to 35 with the percentage of $53.3 \%$ and the rest age intervals of 36 to 45 and less than 25 are $29.7 \%$ and $15 \%$ respectively. Very minor participations from the Ages in between 46 to 55 with $3.1 \%$ and above 55 with $8 \%$. Loyalty is found more in the age group between 26 to 35 years which is considered to be the young age group and expected to be emotionally connected to bank brands

Table 3: Category of respondents' occupation

\begin{tabular}{|c|c|c|c|c|c|}
\hline & & Frequency & Percent & $\begin{array}{l}\text { Valid } \\
\text { Percent }\end{array}$ & $\begin{array}{c}\text { Cumulative } \\
\text { Percent }\end{array}$ \\
\hline \multirow[t]{8}{*}{ Valid } & Professionals & 38 & 14.7 & 14.7 & 14.7 \\
\hline & Govermment job & 70 & & & \\
\hline & holders & 18 & 30.1 & 50.2 & 45.0 \\
\hline & Private job holders & 114 & 44.0 & 44.2 & 89.1 \\
\hline & Business men & 23 & 8.9 & 8.9 & 98.1 \\
\hline & Agriculture & 4 & 1.5 & 1.6 & 99.6 \\
\hline & Others & 1 & .4 & .4 & 100.0 \\
\hline & Total & 258 & 99.6 & 100.0 & \\
\hline Missing & System & 1 & .4 & & \\
\hline Total & & 259 & 100.0 & & \\
\hline
\end{tabular}

Source: statistical output of the survey

As shown in Table 3, the occupation of the respondents with major percentages of $44 \%$ from Private Job holders followed by Government job holders with $30.1 \%$, Professionals with $14.7 \%$, Business men with $8.9 \%$, Agriculture with $1.5 \%$ and others with $0.4 \%$. Hence it can be understood that the loyalty community of nationalized banks are majorly from Private and Government job holders. The more the transactions the more the level of loyalty is well proved since the transactions of the majorly responded groups are considerably high in number so as more loyal. 
Table 4: Coefficients: Impact of brand personality factors on Brand Loyalty

\begin{tabular}{|l|l|l|l|l|l|l|l|l|}
\hline Model & $\begin{array}{l}\text { Contin } \\
\text { uing } \\
\text { the } \\
\text { same } \\
\text { brand }\end{array}$ & $\begin{array}{l}\text { Best } \\
\text { of all } \\
\text { choice } \\
\mathrm{s}\end{array}$ & $\begin{array}{l}\text { Loyal } \\
\text { patro } \\
\text { n of } \\
\text { this } \\
\text { brand }\end{array}$ & $\begin{array}{l}\text { Encourag } \\
\text { e others } \\
\text { to this } \\
\text { brand }\end{array}$ & $\begin{array}{l}\text { Intentio } \\
\text { n to } \\
\text { extend } \\
\text { more } \\
\text { services }\end{array}$ & $\begin{array}{l}\text { Bran } \\
\text { d } \\
\text { first } \\
\text { come } \\
\text { s to } \\
\text { mind }\end{array}$ & $\begin{array}{l}\text { Speak } \\
\text { positivel } \\
\text { y about } \\
\text { this } \\
\text { brand }\end{array}$ & $\begin{array}{l}\text { Intereste } \\
\text { d to } \\
\text { know } \\
\text { more } \\
\text { about } \\
\text { this } \\
\text { brand }\end{array}$ \\
\hline (Constant) & .000 & .000 & .000 & .000 & .007 & .000 & .000 & .000 \\
\hline 1. Sincerity & .973 & .734 & .952 & .036 & .965 & .023 & .005 & .271 \\
\hline 2. Excitement & .054 & .167 & .305 & .876 & .503 & .837 & .832 & .165 \\
\hline 3. Competence & .560 & .177 & .260 & .261 & .971 & .002 & .215 & .152 \\
\hline 4. Sophistication & .158 & .053 & .227 & .050 & .222 & .016 & .049 & .204 \\
\hline 5. Ruggedness & .827 & .836 & .102 & .038 & .111 & .688 & .202 & .456 \\
\hline
\end{tabular}

Source: statistical output of the survey

As depicted in table 4, the consolidated significances of different independent variables of Brand Personality on the dependant variables of Brand loyalty of the Banks are well established and valid at the level of 0.05 . It is clearly found that some variables of brand personality have shown the influence on the different variables of Brand loyalty of the Banks and some are otherwise. The first variable "Sincerity"showssignificance on the dependant variables of Brand loyalty i.e. "Encourage others to buy this brand"with 0.036, "This brand is the first comes to mind" with 0.023 and "Speak positively about this brand" with 0.005 which are less than the significance level of 0.05. Surprisingly the second variable of brand personality "Excitement" has not shown any significance on any item of Brand loyalty. Thirdly, the variable "Competence" shows the significance comes to mind"with 0.002 which is less than the $\mathrm{p}$ value. The fourth variable Sophistication is showing significance on the brand loyalty items of "Encourage others to buy this brand" "This brand is the first comes to mind" and "Speak positively about this brand" with $0.05,0.016$ and 0.049 respectively which are found significant enough at 0.05 level. "Ruggedness" as fifth variable, has shown the significance on the only item of "Encourage others to buy this brand" with 0.038 which is less than $\mathrm{p}$ value.

\section{CONCLUSIONS AND RECOMMENDATIONS}

\section{Conclusions}

Inference made out of the data analysis details the influencing of brand personality factors on the factors of brand loyalty.

- Sincerity amalgamated with choosing the bank for their exactness in advertisement information, their quality of services, Advantages of service features, Privacy and security levels, Easy processing, some unique services have an impact only on certain loyalty elements which motivates the respondents to Encourage others to buy this brand, brand coming to mind while requiring banking services and to Speak positively about this brand and at the same time, the respondents did not assure Continuing the same brand, certifying as the best brand, addressing themselves as the Loyal patrons of brand, Having Intention to extend more services, knowing more about this brand.

- $\quad$ Excitement as another element has been declared insignificant by the respondents without any inhibitions and the factors such as the uniqueness, differentiation, on the only Brand loyalty item of "This brand is the first

specificity, service package style, passion and update are quite ignored by the consumers since they don't find any of the above qualities attributed to any specific brand bank.

- We can understand the importance of the Competence through the previous research, but surprisingly the items of competence element of brand personality have shown significance only on the memory of the brand name while using the banking services. It is surprising to note that the positive significance on memorizing the brand bank is found by the competence elements such as package features, popularity, trust and affordability which have no influence at all on rest of the loyalty items.

- The concept of Sophistication appears in certain banking services such as loans, bonds, investment plans and some special services where the enrichment, wealthy, status and stimuli influence the upper class. In this research Sophistication is showing significance on the three brand loyalty items which will make the consumers not only to come first to the mind but also to encourage others to take an account in this bank brand and also make speaking positively about this brand.

- "Ruggedness" as fifth variable amalgamated with the items such as products bringing good feelings, suits consumer characteristics and preferential has shown the significance on the only item of "Encourage others to buy this brand" whereby the consumers' reaction is to promote the brand to others through word of mouth communication by telling the core and distinguished benefits of the bank.

\section{$>\quad$ Recommendations}

- The bankers may take up certain strategies to retain the consumers by promoting continuity, integrity, patronization, extension and information of the services provided by the bank.

- The bankers should focus on the Unique selling proposition (USP) since the consumers absolutely feel and confirm that the services provided by all the national banks are alike and exceptional services are neither highlighted nor considered.

- In general, competence is as an advantage for any banker. The value addition through competence is found negligible with respect to continuity, patronization, positivity and it is recommended that the bankers should try to make strategies to turn the competencies to be productive with quantified results with high effectiveness.

- Most of the bankers generally focus on the upper class for the motivation will lead to productivity and by continuing the same they may also be motivated to know more information about the new services and developments in the banking industry and acting as a loyal patron as well.

\section{REFERENCE}

1 Aaker, D.A. (2010), "Marketing challenges in the next decade", Journal of Brand Management, Vol. 17 No. 5 , pp. 315-6.

2 Cunningham R (1961) Customer Loyalty to Store and Brand. Harvard Business Review 39:127-137. 
3 Doyle, P. (1990), "Building successful brands: the strategic options", Journal of Consumer Marketing, Vol. 7 No. 2, pp. 5-20.

4 Farquhar, P. H. (1990). Managing brand equity, Journal of Advertising Research, 30(4), 7-12

5 Gashaw, T. Bekalu, W. \&KoppalaVenugopal, (2018) "The Effects of Internal Branding on Employee Brand Commitment: In Case of University of Gondar, Ethiopia" International Journal of Innovative Research and Practices, Vol 6 Issue 3, PP: 12-32

6 Galton, F. (1884), "Measurement of character", Fortnightly Review, Vol. 36, pp. 179-85.

7 Gremler D. and Brown S.W. (1996), the loyalty ripple effect: appreciating the full value of customers, International Journal of Service Industry Management 10(3): 271-93

8 Keller K. L. 2003. Strategic Brand Management Building, Measuring, and Managing Brand Equity, $2^{\text {nd }}$ ed. Prentice Hall, Upper Saddle River, NJ.

9 Kem Z.K. Zhang, Salsa Wang and Sesia J. Zhao, 2012; effect of brand personality on brand loyalty in companies' microblogs

10 Kim, C. K., Han, D., \& Park, S. B. (2001). The effect of brand personality and brand identification on brand loyalty: Applying the theory of social identification. Japanese psychological research, 43(4), 195-206.

11 Krishnamurthi, L. and Raj, S.P., 1991. An empirical Analysis of the Relationship between Brand

12 Martineau, Pierre (1958): The Personality of the Retail Store. Harvard Business Review. 36(1), pg. 47-55

13 Reichheld, F.F. (1996). The Loyalty Effect, Harvard Business School Press, Boston, MA.

14 Venugopal K., (2013) "A way forward to Branch Banking",Journal ofEconomic and Social Research, Economic and Social Research Institute (ESRI), Rajasthan. Vol 4, Jul 2013, pp.26-31

15 Zeithaml, V.A. and Berry, L.L. (1996), "The behavioral consequences of service quality", Journal of Marketing, Vol. 60 No. 2, pp. 31-46. 